\title{
KEDEWASAAN UNTUK MENIKAH
}

\author{
Oleh : \\ Sun Choirol Ummah \\ MKU-UNY \\ Email : sun.ummah@gmail.com
}

\begin{abstract}
Abstrak : Rumah tangga yang kekal dan harmonis seringkali dibangun oleh suami istri yang memiliki kedewasaan, baik fisik maupun rohani karena mereka telah diikat oleh rasa tanggung jawab yang sempurna. Mereka mampu bereaksi dan bertindak secara tepat dalam setiap situasi dan masalah serta berani menghadapi kenyataan, mau menerima resiko dari segala perbuatannya tidak membohongi orang lain, apalagi membohongi dirinya sendiri. Walaupun kedewasaan bukan merupakan syarat sahnya suatu perkawinan dalam Islam namun ternyata tujuan perkawinan akan landing dengan manis bila didukung kedewasaan suami istri. Modal cinta memang penting tetapi cinta yang diikuti oleh rasa tanggung jawab untuk mengembangkan diri (extention of the self). Kedewasaan anak tergantung situasi, kondisi, dan kebijakan pemerintah masing-masing negara. Kedewasaan pada dasarnya dapat ditentukan dengan umur dan dapat pula dengan tanda-tanda, yakni antara umur16 tahun sampai 30 tahun dan ditandai dengan perubahan fisiknya.
\end{abstract}

Kata Kunci : Kedewasaan, Tanggungjawab, Menikah.

\section{Pendahuluan}

Kisah Syekh Puji (47 th) yang menikahi gadis di bawah umur, Lutfiana Ulfah (12 th) beberapa tahun yang lalu sontak menimbulkan berbagai macam tanggapan. Di antara masyarakat, ada yang memilih diam, dengan alasan bahwa dalam al-Quran maupun Hadis tidak ada larangan menikahi gadis dibawah umur, namun sebagian masyarakat yang lain mengecam, seraya memberikan alasan bahwa Undang-undang Perkawinan tahun 1974 dan begitu pula dalam Kompilasi Hukum Islam tidak mensyaratkan pernikahan gadis dibawah umur 16 tahun. Undang-undang ini merupakan dasar pijakan para hakim Islam Indonesia, untuk menekan lajunya pernikahan usia dini mengingat tingkat kedewasaan calon suami maupun isteri sangat diutamakan, demi terciptanya keluarga yang sakinah mawaddah wa rahmah.Selain itu, Komnas HAM untuk Perlindungan Anak juga mengupayakan agar pernikahan tersebut ditunda, mengingat hak mendapatkan pendidikan dasar bagi Ulfah belum sempurna, dan Ulfah juga belum cukup dewasa meskipun berkali-kali beralasan kesediaannya menikah atas dasar rasa cinta. Begitu pula kalangan 
kedokteran dan pemerhati hak perempuan, memberikan alasan bahwa alat-alat reproduksi Ulfah belum siap menerima beban tanggung jawab bila terjadi kehamilan.

Tujuan mendirikan rumah tangga yang kekal dan harmonis yang diikat oleh tali pernikahan merupakan hal yang suci. Namun demikian tidak jarang terjadi bahwa tujuan yang mulia tersebut tidak sesuai dengan yang diharapkan. Suatu tugas mulia bisa saja tidak mencapai sasaran yang diharapkan bila kendalinya dipegang oleh orang yang tidak pantas untuk itu, termasuk dalam pembinaan rumah tangga. Apabila suami isteri atau salah satu dari mereka belum memiliki kedewasaan, baik fisik ataupun rohani, maka pembinaan rumah tangga itu akan menjadi sulit. Menurut Dr. Sarlito Wirawan Sarwono, orang muda yang akan menempuh kehidupan rumah tangga hanya dapat mengartikan cinta sebagai suatu keindahan dan romantisme belaka. Mereka baru memiliki cinta emosi, karena belum diikat oleh rasa tanggung jawab yang sempurna (Sarwono, 1981:12). Sedangkan perilaku tanggung jawab merupakan indikasi kedewasaan (Yanggo dan Anshary, 1994: 61). Dalam hal ini tanggung jawab mengandung dua hal penting. Pertama, orang yang bertanggung jawab harus dapat bereaksi dan bertindak secara tepat dalam setiap situasi dan masalah. Kedua, berani menghadapi kenyataan, mau menerima resiko dari segala perbuatannya tidak membohongi orang lain, apalagi membohongi dirinya sendiri (Sarwono, 1981:13). Karena perlunya rasa tanggung jawab inilah maka dalam perkawinan, Islam memiliki rukun dan syarat tertentu yang harus dipenuhi.

Menurut Imam Malik dan Syafi'i, salah satu syarat sahnya nikah ialah adanya wali. Namun demikian, Daud al-Zahiri berpendapat bahwa wali hanya diperlukan bagi perempuan gadis (Rusyd,1960: 9). Daud berpendapat demikian tampaknya dikarenakan ia memandang perempuan gadis sebagai orang yang belum mampu memikul tanggung jawab secara penuh atau belum dewasa. Berbalik arah dengan perempuan janda, karena janda dinilainya telah mengetahui arti rumah tangga dan mengetahui akan tanggung jawabnya, ia tidak disyaratkan memakai wali dalam pernikahan. Pendirian yang hampir sejalan dengan pendapat Daud itu terlihat pula pada pendapat Abu Hanifah yang tidak mensyaratkan adanya wali asalkan suami dari wanita itu sebanding (sekufu). Abu Hanifah dan muridnya, Abu Yusuf, malah membolehkan wanita menikahkan dirinya asalkan wanita itu telah dewasa, dan tidak 
harus janda. Menurutnya adanya wali dalam pernikahan hanyalah sunnat saja, yaitu untuk memelihara kemuliaan dan kehormatan wanita (Sabiq, 1973:128).

Terlepas dari perbedaan pendapat di atas, kedewasaan merupakan hal yang penting sebagai bekal untuk memikul tanggung jawab dalam perkawinan. Untuk memudahkan pemahaman tulisan ini berikut akan diuraikan urgensi kedewasaan dalam membina rumah tangga dan usia kedewasaan menurut Islam.

\section{Urgensi Kedewasaan dalam Membina Rumah Tangga}

Perkawinan dapat diibaratkan sebagai kontrak yang suci dan merupakan tiang utama pembentukan suatu keluarga yang baik. Begitu pentingnya lembaga ini, maka Islam menentukan sejumlah aturan dan tindakan untuk mengokohkan rumah tangga yang dibentuk itu. Sebagian dari tindakan itu wajib diusahakan sejak pra pernikahan, sebagian lagi ada yang mesti dijaga sejak selesainya akad nikah guna memudahkan jalan bagi suami isteri untuk membina rumah tangga, sedangkan tindakan lain yang mesti diusahakan adalah tatkala adanya gangguan dan goncanganterhadap rumah tangga itu ( Syaltut,1986:147). Persoalan kehidupan rumah tangga pra perkawinan, misalnya berupa pertanyaan, apakah kita dapat mewujudkan rumah tangga yang bahagia? Barangkali semua orang akan mengatakan bahwa masalah perkawinan bukanlah persoalan yang enteng, dan tidak semua orang dapat mengarunginya dengan sukses. Orang yang sudah dewasa, fisik dan mental belum tentu bisa membina dan mendirikan rumah tangga secara sempurna, apalagi orang muda yang belum dewasa.Secara rasional kita dapat menyimpulkan bahwamasalah kedewasaan merupakan persoalan yang penting yang mempunyai pengaruh yang tidak kecil terhadap keberhasilan rumah tangga.

Memang, pada dasarnya Islam tidak pernah mensyaratkan sahnya suatu perkawinan karena kedewasaan pihak-pihak yang akan menikah. Artinya suatu perkawinan tetap menjadi sah apabila rukun dan syaratnya terpenuhi, tanpa mengharuskan usia kedewasaan calon suami isteri. Tidak adanya persyaratan kedewasaaan suami isteri itu merupakan kemudahan yang diberikan agama, karena ada segi-segi positif lain yang ingin dituju. Akan tetapi, karena persoalan perkawinan bukanlah hal yang sederhana, maka agama mensyaratkan adanya beberapa rukun dan syarat guna menumbuhkan rasa tanggung jawab. 
Dalam masa pra pernikahan umpamanya, perlu saling mengenal, antara kedua pihak calon mempelai. Setiap pihak perlu mengenal calon pasangan hidupnya, terutama tentang akhlak dan agamanya.Yang dapat melakukan penilaian itu tentulah yang sudah dewasa.Adanya pinangan (khitab) merupakan saat berpikir bagi suatu pihak untuk menilai calon teman hidupnya. Menurut Jumhur, khitab al-nikah itu tidak wajib, sedangkan menurut AbuDaud adalah wajib (Rusyd, 1960:2). Keberadaan wali yang sangat menentukan dalam penerimaan pinangan boleh dijadikan indikasi bahwa wali, sebagai orang yang sudah dewasa, akan dapat memberikan pandangan yang jauh ke depan bagi kepentingan orang yang berada di bawah perwaliannya.

Kebebasan untuk menerima atau menolak suatu pinangan pernikahan merupakan suatu sikap yang dijamin agama. Hal ini berarti bahwa kawin paksa harus dihindarkan, dan setiap calon suami isteri haruslah diminta prsetujuannya untuk dinikahkan. Disebutkan dalam Hadis yang diriwayatkan oleh Bukhari dan Muslim serta Nasa'i dari Abu Hurairah yang artinya "Tidak dinikahkan wanita janda sebelum diperintahkannya dan tidak pula dinikahkan wanita gadis sebelum diminta izinnya”. Hadis ini selain menunjukkan perlunya meminta persetujuan kepada calon mempelai wanita untuk dinikahkan, juga menunjukkan adanya perbedaan antara perempuan janda dan perempuan gadis.

Mengapa ada perbedaaan itu? Dari sumber syariat tidak didapati illat perbedaan itu. Namun secara logis dapat dikatakan bahwa wanita janda dipandang lebih tahu arti pernikahan dan tanggung jawabnya dalam rumah tangga bila dibandingkan dengan perempuan gadis yang memang masih belum berpengalaman tentang hal itu. Dengan kata lain mungkin tidaklah salah bila dikatakan bahwa wanita janda itu telah dewasa, sementara wanita gadis yang belum berpengalaman belum memiliki kedewasaan. Ini dikuatkan dengan Hadis riwayat Bukhari, Muslim dan Abu Daud yang artinya "Perempuan janda itu lebih berhak atas dirinya dari walinya dan perempuan gadis itu diminta keizinannya untuk dinikahkan."

Kalau dipikir lebih jauh, maka adanya pembedaan janda dan gadis tampaknya lebih berorientasi pada kesanggupan untuk mengemban amanat Allah dalam hidup berumah tangga.Di sinilah barangkali arti penting sebuah kedewasaan sebagai modal menempuh perkawinan, sehingga calon suami isteri diharapkan dapat membina 
rumah tangga yang mandiri. Pandangan tentang perlunya kedewasaan ini sejalan dengan pendirian Abu Hanifah dan Abu Yusuf yang menyebutkan bahwa wali bukanlah termasuk syarat sahnya perkawinan - bila wanita yang akan kawin itu telah baligh (dewasa), dan calon suaminya sekufu - dan sependapat dengan Abu Daud yang hanya mengharuskan adanya wali bagi perempuan gadis (Sabiq, 1973: 128).

Apabila didasarkan pada Psikologi, maka tampak sekali tidak sempurnanya suatu tanggung jawab untuk membina rumah tangga bila hanya mengandalkan rasa cinta semata-mata. Cinta memang merupakan modal untuk membina rumah tangga, namun cinta yang baik bukan hanya sekedar cinta emosi, tetapi cinta yang diikuti oleh rasa tanggung jawab untuk mengembangkan diri (extention of the self), yaitu diri pribadi dikembangluaskan kepada diri yang lain sehingga pasangan hidupnya dipandang sebagai bagian dari dirinya sendiri. Hal itu hanya bisa terwujud dalam diri orang yang memiliki kedewasaan (Sarwono, 1981:13).

Persoalan lain yang sangat perlu diperhatikan ialah kehidupan rumah tangga setelah akad nikah. Rasanya cukup sulit untuk mewujudkan suatu kehidupan rumah tangga yang baik tanpa dibarengi oleh kedewasaan bertindak dari suami isteri.Tanpa kedewasaan, persoalan hidup berumah tangga tidak jarang malah membangkitkan emosi yang sulit dikendalikan.Masalah nafkah, misalnya, baik untuk isteri maupun anak-anak, bisa terabaikan bila tidak didasari oleh kesadaran yang tinggi. Betapa sulitnya pembinaan dan pendidikan anak-anak tanpa didasari oleh kematangan suami isteri.Lebih jauh lagi, dapat dibayangkan betapa sulitnya kehidupan suami isteri yang belum dewasa itu bila rumah tangga mereka digoncang oleh perbedaan pendapat.

Disebabkan belum adanya kematangan suami isteri, aturan-aturan agama yang memberikan pedoman untuk mengatasi perbedaan pendapat dalam rumah tangga sering dikalahkan oleh emosi yang tidak terkontrol. Oleh karena itu, bubarnya kehidupan rumah tangga melalui perceraian sangat mudah menggoda suami isteri yang tidak mampu mengendalikan emosi serta yang tidak mempunyai pandangan jauh kedepan. Pendek kata, tujuan dan hikmah pernikahan sangat sulit terwujud apabila para pengayuh bahtera kehidupan rumah tangga itu belum mempunyai kedewasaan. Dengan demikian, maka kedewasaan merupakan salah satu faktor yang turut menentukan berhasil atau tidaknya suatu rumah tangga. 


\section{Usia Kedewasaan Menurut Islam}

Uraian di atas telah memperlihatkan bahwa faktor kedewasaan merupakan kondisi yang amat penting, kendatipun tidak termasuk ke dalam rukun maupun syarat nikah. Bila diteliti secara seksama, ajaran Islam tidak pernah memberikan batasan yang definitif pada usia berapa seseorang dianggap telah dewasa. Memang di setiap daerah dan zaman memiliki kelainan dengan daerah dan zaman yang lain, yang sangat berpengaruh terhadap cepat atau lambatnya usia kedewasaan seseorang.

Di sisi lain, masalah pernikahan merupakan urusan hubungan antar manusia (mu'amalah) yang oleh agama hanya diatur dalam bentuk prinsip-prinsip umum. Tidak adanya ketentuan agama tentang batas usia minimal dan maksimal untuk menikah dapat dianggap sebagai suatu rahmat. Maka kedewasaan untuk menikah termasuk masalah ijtihadiyah, dalam arti kata diberi kesempatan untuk berijtihad pada usia berapa seseorang pantas menikah.

Nabi Muhammad Saw. melangsungkan akad nikah dengan Aisyah ketika ia baru berusia enam tahun, dan dalam umur sembilan tahun isterinya telah digaulinya. Hal ini diakui sendiri oleh Aisyah umm al-mukminin dalam hadis yang artinya "Dari Aisyah, bahwa Nabi Saw.telah menikahinya ketika ia berusia enam tahun, dan Rasulullah telah menggaulinya ketika dia berusia sembilan tahun”. Hadis ini hanyalah bersifat khabariyah (kabar) belaka tentang perkawinan Nabi. Di dalamnya tidak dijumpai khitab (pernyataan), baik berupa khitab al-thalab yang mesti diikuti ataupun khitab al-tark supaya ditinggalkan. Karena itu, pernyataan usia yang ada dalam hadis di atas tidak dapat disimpulkan sebagai pernyataan batas usia terendah kebolehan melangsungkan pernikahan bagi kaum wanita.

Batas usia untuk menikah bagi kaum pria juga tidak ada ketentuannya. Adanya seruan Nabi kepada kaum pemuda yang mampu melakukan pernikahan supaya menikah bukanlah suatu kemestian pembatas usia, seperti hadis yang diriwayatkan oleh Bukhari, Muslim dari Abdullah bin Mas'ud yang artinya: "Wahai para pemuda, siapa saja di antara kamu yang sudah mampu menanggung biaya, maka hendaklah ia kawin" (Bukhari, tt: 22). Kendatipun al syabab, jamak dari al-syabb, berarti pemuda yang berusia sebelum 30 tahun.

Menurut para ulama, masalah usia dalam pernikahan sangat erat hubungannya dengan kecakapan bertindak. Hal ini tentu dapat dimengerti karena perkawinan 
merupakan perbuatan hukum yang meminta tanggung jawab dan dikenai kewajibankewajiban tertentu. Maka, setiap orang yang akan berumah tangga diminta kemampuannya secara utuh. Menurut bahasa Arab "kemampuan" disebut ahlun yang berarti "layak, pantas" (Ash-Siddieqi, 1975:240). Para ulama selalu mendefinisikan kemampuan itu dengan shalahuyyatuhu liwujub al-huquq al-masyru'ah lahu wa 'alaih, yaitu kepantasan seseorang untuk menerima hak-hak dan memenuhi kewajiban-kewajiban yang diberikan syara' (Al-Rahawi, 1315H/1993: 930).

Kepantasan di sini berkaitan dengan ahliyah al wujub (kemampuan untuk mempunyai dan menanggung hak), sedangkan kepantasan bertindak menyangkut kepantasan seseorang untuk dapat berbuat hukum secara utuh, yang dalam istilah fikih disebut ahliyah al-ada' (kemampuan untuk melahirkan kewajiban atas dirinya dan hak untuk orang lain). Oleh ulama Ushul Fikih kecakapan bertindak itu didefinisikan sebagai "kepatutan seseorang terhadap munculnya suatu perbuatan (tindakan) dari dirinya menurut cara yang ditetapkan syara,"(Al-Rahawi, 1315H/1993: 930).

Menurut kesepakatan para ulama, yang menjadi dasar kecakapan bertindak adalah akal. Apabila akal seseorang masih kurang, maka ia belum diberi kewajiban. Sebaliknya, jika akalnya telah sempurna, ia wajib menunaikan beban tugas yang dipikulkan kepadanya. Berdasarkan hal ini, maka kecakapan bertindak ada yang bersifat teratas (ahliyah al-ada' al-nuqshan) dan ada yang bersifat sempurna (ahliyah al-ada' al-kamilah). Kalau keterangan dan pembagian ini dihubungkan dengan perkawinan, maka timbul pertanyaan: usia berapakah seseorang dipandang cakap untuk membangun rumah tangga?

Sebelum menjawab pertanyaan ini terlebih dahulu perlu diperhatikan firman Allah dalam surat al-Nisa' ayat 6 yang artinya, "Dan ujilah anak yatim itu sampai mereka cukup umur untuk kawin. Kemudian jika menurut pendapatmu mereka telah cerdas (pandai memelihara harta), maka serahkanlah kepada mereka hartahartanya" (QS. Ali Imran (3): 6). Pada dasarnya ayat ini berisi anjuran supaya memperhatikan anak yatim tentang keagamaannya, usaha-usahanya, dan kelakuannya sehingga mereka dapat dipercaya. Orang-orang telah dapat dipercaya secara sempurna berarti telah dapat diberi tanggung jawab secara penuh, atau dengan kata lain, orang itu telah dewasa. 
Ketika menafsirkan ayat di atas, Muhammad Rasyid Ridha mengatakan bahwa bulugh an-nikah berarti sampainya seseorang kepada umur untuk menikah, yakni sampai bermimpi. Pada umur ini, katanya, seseorang telah bisa melahirkan anak dan menurunkan keturunan, sehingga tergerak hatinya untuk menikah. Pada umur ini kepadanya telah dibebankan hukum-hukum agama, seperti ibadah dan muamalah serta diterapkannya hudud. Karena itu, maka rusyd adalah kepantasan seseorang dalam ber-tasharruf serta mendatangkan kebaikan. Hal ini merupakan bukti kesempurnaan akalnya (Ridha, 1325 H/2003: 387). Menurut ulama Syafi'iyyah, rusyd-nya anak kecil ialah apabila telah tampak kebaikan tindakannya dalam soal beragama dan harta benda (al-Jaziri, 1985: 353).

Berdasarkan uraian di atas, maka kedewasaan ditentukan dengan "mimpi" dan "rusyd", akan tetapi umur mimpi dan rusyd kadang-kadang tidak sama dan sukar ditentukan. Seseorang yang telah bermimpi ada kalanya belum rusyd dalam tindakannya.Hal ini dapat dibuktikan dalam perbuatan sehari-hari.Karena itu, kedewasaan pada dasarnya dapat ditentukan dengan umur dan dapat pula dengan tanda-tanda.Menentukan kedewasaan anak dengan tanda-tanda yakni dengan datangnya masa haid, kerasnya suara, tumbuhnya bulu ketiak, atau tumbuhnya bulu kasar di sekitar kemaluan (al-Jaziri, 1985: 350).

Sedangkan menentukan kedewasaan dengan umur, terdapat berbagai pendapat. Ulama Syafi'iyah dan Hanabilah menentukan bahwa masa dewasa itu mulai umur 15 tahun. Walaupun mereka dapat menerima kedewasaan dengan tanda-tanda seperti di atas, tetapi karena tanda-tanda itu datangnya tidak sama untuk semua orang, maka kedewasaan ditentukan dengan umur. Disamakannya masa kedewasaan untuk lakilaki dan perempuan adalah karena kedewasaan itu ditentukan dengan akal. Dengan akallah terjadinya taklif, dan karena akal pulalah adanya hukum (Audah, 1964: 603).

Abu Hanifah berpendapat bahwa kedewasaan itu datangnya mulai usia 19 tahun bagi laki-laki dan 17 tahun bagi perempuan. Sedangkan Imam Malik menetapkan 18 tahun, baik bagi laki-laki maupun perempuan. (Audah, 1964: 603). Mereka beralasan dengan "ketentuan dewasa menurut syara' ialah mimpi", karenanya mendasarkan hukum kepada mimpi itu saja. Mimpi tidak diharapkan lagi datangnya bila usia telah 18 tahun. Umur antara 15 tahun sampai 18 tahun masih 
diharapkan datangnya. Karena itu, ditetapkanlah bahwa umur dewasa itu pada usia 18 tahun (Audah, 1964: 603).

Sarlito Wirawan Sarwono melihat bahwa usia kedewasaan untuk siapnya seseorang memasuki hidup berumah tangga harus diperpanjang menjadi 20 tahun untuk perempuan dan 25 tahun untuk laki-laki. Hal ini diperlukan karena zaman modern menuntut untuk mewujudkan kemaslahatan dan menghindari kerusakan, baik dari segi kesehatan maupun tanggung jawab sosial (Sarwono, 1983: 23).

Marc Hendry Frank mengatakan bahwa perkawinan sebaiknya dilakukan antara usia 20 sampai 25 tahun bagi perempuan dan antara 25 sampai 30 tahun bagi lakilaki. Tinjauan ini juga didasarkan atas pertimbangan kesehatan (Yanggo dan Anshary, 1994: 70). Para ahli Ilmu Jiwa Agama menilai bahwa kematangan beragama pada seseorang tidak terjadi sebelum usia 25 tahun (Yanggo dan Anshary, 1994:71).

Di Indonesia, melalui Undang-undang No. 1 tahun 1974 tentang Perkawinan, atau sering disebut dengan Undang-undang Perkawinan, ditetapkan usia nikah untuk laki-laki 19 tahun dan untuk perempuan 16 tahun. Ditambahkan juga bahwa jika keduanya belum berusia 21 tahun masih harus mendapatkan izin dari orang tua atau walinya. Untuk zaman sekarang perkawinan di bawah 21 tahun ini sudah tidak sebanyak beberapa tahun yang lalu.

Perbedaan pendapat yang tidak terlalu tajam di atas menunjukkan bahwa berbagai faktor ikut menentukan cepat atau lambatnya seseorang mencapai usia kedewasaan, terutama kedewasaan untuk berkeluarga. Menurut kondisi Indonesia sekarang, usia yang tepat bagi seseorang untuk nikah adalah sekurang-kurangnya umur 20 tahun bagi perempuan dan 25 tahun bagi laki-laki. Mengapa demikian? Sebab, sebelum usia tersebut calon suami isteri perlu mempersiapkan diri sebaik mungkin, sehingga pada usia itu seseorang telah matang jasmaninya, sempurna akalnya dan dapat diterima sebagai anggota masyarakat secara utuh. Pada usia itu, menurut Allport, seseorang telah bisa memekarkan diri (extention of the self) kepada teman hidupnya, di samping bisa menilai dirinya secara objektif dan mempunyai pandangan tentang posisi dirinya dalam mengatur tingkah laku secara konsisten (Yanggo dan Anshary, 1994: 71). Dengan kematangan itu kehidupan rumah tangga yang dibinanya diharapkan dapat berjalan sesuai ketentuan agama. 
Perlu dicatat, bahwa angka-angka usia di atas tidaklah selalu cocok untuk setiap wilayah di dunia ini. Setiap wilayah dapat saja menentukan usia kedewasaan untuk menikah sesuai dengan masa dan kondisi yang ada. Kondisi sosial budaya serta ekonomi turut andil besar dalam mengkondisikan seseorang untuk mengambil keputusan dalam menikah.

\section{Penutup}

Sebagai akhir dari tulisan ini, dapat dikemukan bahwa agama Islam secara eksplisit tidak pernah mengharuskan kedewasaan sebagai salah satu syarat atau rukun nikah. Islam hanya mengemukakan bahwa lembaga perkawinan merupakan suatu institusi suci yang memiliki hikmah menyelamatakan kehidupan manusia di dunia dan akhirat. Karena pentingnya lembaga perkawinan itu, termasuk untuk membina generasi yang akan datang dari setiap keluarga, maka secara implisit terkandung suatu anjuran supaya siapa saja yang memasuki kehiduapan rumah tangga hendaknya telah memiliki kematangan, baik fisik maupun mental. Dalam hal inilah persoalan kedewasaan merupakan suatu unsur yang tidak boleh diabaikan.

Kedewasaan sangat dipengaruhi oleh kondisi sosial, ekonomi, pendidikan, dan lingkungan. Karena itu, usia kedewasaan antara satu daerah dengan daerah yang lain, antara suatu masa dengan masa yang lain, dan bahwa antara satu orang dengan orang yang lain tidaklah selalu sama. Walaupun demikian, untuk warga suatu masyarakat di suatu daerah pada suatu masa yang sama tidaklah akan memiliki perbedaaan yang begitu mencolok. Dalam lapangan ini pula para ahli boleh saja melakukan ijtihad tentang usia berapakan sebaiknya usia terendah untuk seseorang melakukan perkawinan, sehingga cita-cita untuk mendirikan rumah tangga yang bahagia yang diridhai oleh Allah tidak terlalu sulit diwujudkan.

\section{DAFTAR PUSTAKA}

Ahmad bin Rusyd. Muhammad bin Ahmad bin Muhammad bin, 1960. Bidayah alMujtahid, juz II, Mesir: Syarikah Maktabah wa Muthaba'ah al-Baby al-Halaby wa Awladih. 
Audah, Abdul Qadir.1964. .Al-Tasyrif al-Jina'iy al-Islamiy, Juz I, Kairo: Dar alUrubah.

Bukhari., tt., Shahih al-Bukhari, juz VI, Dar waMathabi' al-Sya'b.

Al-Jaziri, Abdul Rahma. 1985. .Kitab al-Fiqh 'ala al-Mazahib al-Arba'ah, Juz II, Beirut: Dar al-Fikr.

Karim, Helmi. 1994. "Kedewasaan untuk Menikah" dalam Chuzaimah T. Yanggo dan HA. Hafiz Anshari AZ (ed.), Problematika Hukum Islam Kontemporer, Jilid II, Jakarta: Pustaka Firdaus.

Al-Rahawi. 1315H/1993. Syarh al-Manar wa Khawasyih min 'Ilm al-Ushul, Mesir: Dar al-Sa'adah.

Ridha. Muhammad Rasyid. 1325H/2003. Tafsir al-Manar, Juz IV, Mesir: Al-Manar.

Sarwono. Sarlito Wirawan. 1981., "Memilih Pasangan dan Merencanakan Perkawinan", dalam Bina Keluarga, No. 99, Jakarta: BKKBN.

-----------.1983. Membina Perkawinan yang Berbahagia, Jakarta: Bulan Bintang.

Sabiq, Sayyid. 1973. Fiqh al-Sunnah, juz II, Beirut: Dar al-Kitab al-'Arabiy.

Ash-Siddieqi, Hasbie. 1975. Pengantar Hukum Islam, jilid II, Jakarta: Bulan Bintang.

Syaltut, Mahmud. 1986. .Al-Islam Aqidah wa Syari'ah, Kairo: Dar al-Qalam.

Yanggo, Chuzaemah T., dan Anshary, Hafiz. 1994. Problematika Hukum Islam Kontemporer, Jakarta: PT Pustaka Firdaus. 